\title{
Oxygen fugacity as a control on the distribution of diamond in the sub-cratonic lithospheric mantle
}

\author{
Patrick Y. Goodarzi ${ }^{1}$, Andrew J. Berry ${ }^{1}$, D. Graham Pearson ${ }^{2}$, Gregory M. Yaxley ${ }^{1}$ and \\ Matt Newville ${ }^{3}$ \\ ${ }^{1}$ Australian National University, Canberra, Australia, patrick.goodarzi@anu.edu.au, \\ andrew.berry@anu.edu.au,greg.yaxley@anu.edu.au \\ ${ }^{2}$ University of Alberta, Edmonton, Canada, graham.pearson@ualberta.ca \\ ${ }^{3}$ University of Chicago, Chicago,USA,newville@cars.uchicago.edu
}

\section{Oxygen fugacity and metasomatism}

For diamond to exist in the lithospheric mantle the ambient oxygen fugacity $\left(f \mathrm{O}_{2}\right)$ must be sufficiently reduced for diamond to be the stable phase of carbon. Garnet peridotite xenoliths record the $f \mathrm{O}_{2}$ at which they equilibrated prior to kimberlite eruption by the oxidation state of $\mathrm{Fe}\left(\mathrm{Fe}^{3+} / \Sigma \mathrm{Fe}\right)$ in garnet. It has been asserted that, at pressures above the graphite-diamond transition, the lithospheric mantle beneath diamond-bearing kimberlites (e.g. Diavik, Finsch, Udachnaya) was adequately reduced for diamond to be stable. Metasomatism of lithospheric mantle by fluid or melt is, however, thought to perturb $f \mathrm{O}_{2}$ to more oxidising conditions, potentially sufficient to destabilise diamond (Hanger et al. 2015). Metasomatism of this nature is most discernibly recorded by enrichment of high-field strength elements (HFSE) coupled with "normal" chondrite-normalised rare earth element $\left(\mathrm{REE}_{\mathrm{N}}\right)$ patterns in garnet, but the relationship with $f \mathrm{O}_{2}$ change remains poorly understood. Studies of this type have been limited predominantly to peridotite samples from economically diamondiferous kimberlites. Here we present $f \mathrm{O}_{2}$ results for garnet-peridotite xenoliths from two non-diamondiferous kimberlites.

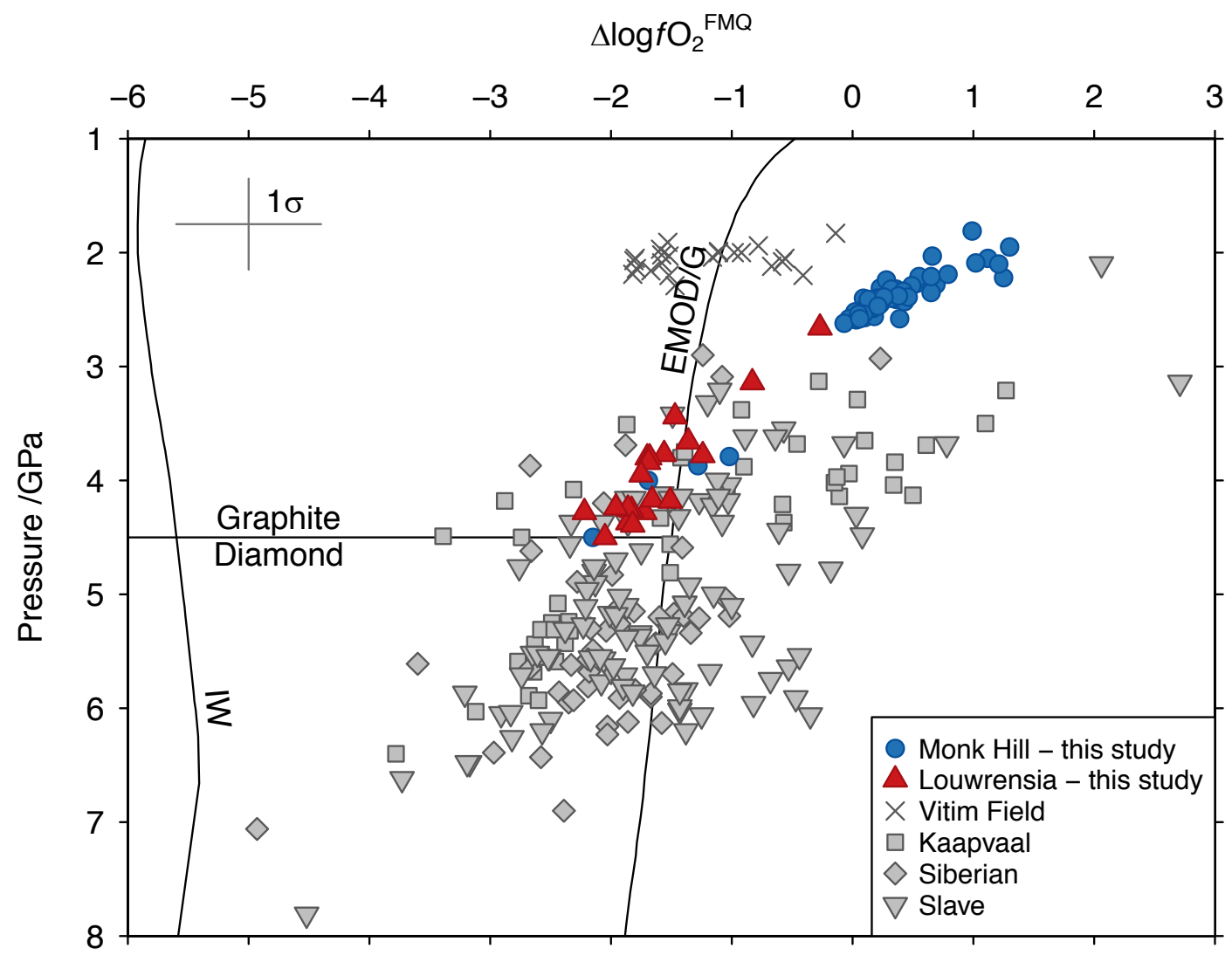

Figure 1: Pressure vs. $\Delta \log f \mathrm{O}_{2}{ }^{[\mathrm{FMQ}]}$ for xenoliths from Monk Hill and Louwrensia. A global dataset of garnetbearing xenoliths is shown for comparison. The iron-wüstite buffer (IW) and the enstatite-magnesite-olivinediamond/graphite reaction (EMOD/G) were calculated along a geotherm derived from Kaapvaal xenoliths. 


\section{Samples}

(1) The Louwrensia kimberlite is one of over 70 non-diamondiferous pipes within the off-cratonic Gibeon kimberlite field of south-central Namibia. Twenty-three lherzolite samples have been well characterized in previous studies (Boyd et al. 2004; Pearson et al. 2004) and were found to derive from pressures between 2.7 and $4.8 \mathrm{GPa}$. The geothermal gradient defined by these samples indicates that the lithosphere at the time of eruption was comparable in thickness to that of the nearby diamondbearing Kaapvaal craton (Mather et al. 2011).

(2) The Monk Hill kimberlite is one of a cluster of non-diamondiferous pipes within the Adelaide Fold Belt of South Australia. Thirty-six lherzolite samples were derived from pressures between 1.8 and 4.6 GPa (Tappert et al. 2011).

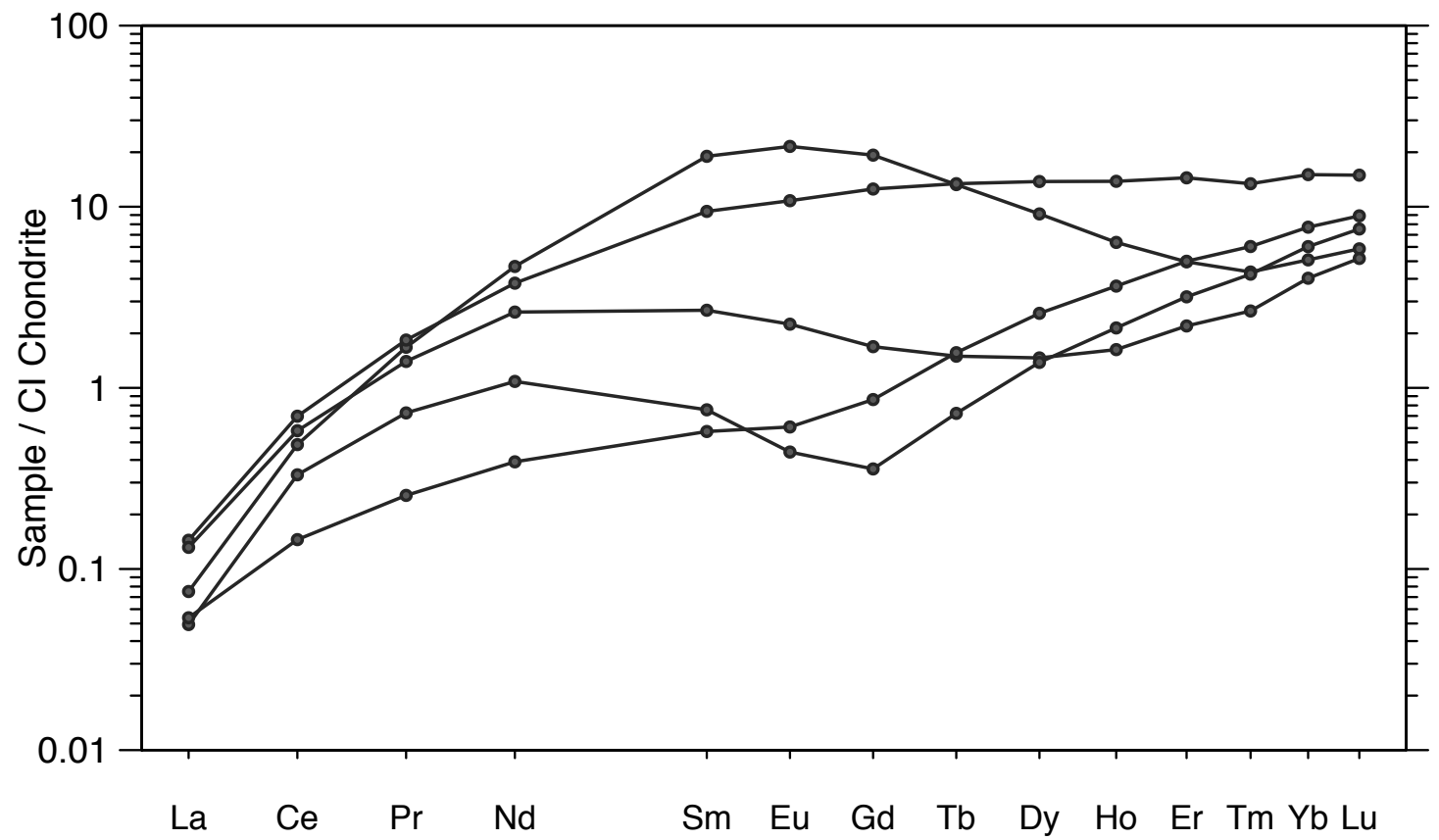

Figure 2: Chondrite-normalised REE concentrations in garnet from five Louwrensia samples, representative of the observed diversity.

\section{Fe K-edge XANES and results}

Determining $\mathrm{Fe}^{3+} / \Sigma \mathrm{Fe}$ of garnet for large numbers of samples was previously challenging due to long acquisition times (Mössbauer spectroscopy) or onerous analytical procedures (the electron microprobe "flank method"). Here, $\mathrm{Fe}^{3+} / \sum \mathrm{Fe}$ of garnet was determined by Fe K-edge X-ray Absorption Near Edge Structure (XANES) spectroscopy following the approach of Berry et al. (2010), Yaxley et al. (2012), and Hanger et al. (2015), by which $\mathrm{Fe}^{3+} / \sum \mathrm{Fe}$ can be determined with micron spatial resolution in less than 10 minutes. $\mathrm{Fe}^{3+} / \sum \mathrm{Fe}$ was quantified using the intensity of the post-edge minimum - a spectral feature that correlates well with known $\mathrm{Fe}^{3+} / \sum \mathrm{Fe}$ in peridotitic garnet standards $\left(\mathrm{R}^{2}=0.93\right)$ - and was reproducible to a precision of $0.002(1 \sigma, \mathrm{n}=8)$. The resultant $f \mathrm{O}_{2}$ was computed using the recent garnetoxybarometer calibration of Miller et al. (2016). $\Delta \log f \mathrm{O}_{2}{ }^{[\mathrm{FMQ}]}$ (where FMQ is the fayalite-magnetitequartz buffer) ranged between -0.27 and -2.22 for the Louwrensia samples, and between and 1.3 and -2.15 for those from Monk Hill. These results are the first determination of the $f_{2}$ of the lithospheric mantle beneath the Australian craton and circum-cratonic Kaapvaal. Both are consistent with $f \mathrm{O}_{2}$-depth profiles from the Kaapvaal, Slave, and Siberian cratons (Fig. 1), and comparison with samples from other kimberlites in the Kaapvaal region highlights the consistent ambient $f \mathrm{O}_{2}$ in this part of the lithosphere over the 50 Mya interval between the eruption of Finsch (120 Ma) and Louwrensia (70 Ma). 
The $f \mathrm{O}_{2} \mathrm{~s}$ determined for both sample suites are sufficiently reduced for diamond to be stable at an appropriate lithospheric thickness. The absence of diamonds in these pipes is therefore explained by the kimberlite not sampling the diamond stability window.

Trace element concentrations in garnet and clinopyroxene were determined by LA-ICP-MS. REE $\mathrm{N}_{\mathrm{N}}$ patterns in garnet from the Louwrensia samples exhibit diverse shapes, from normal to sinusoidal to sloped (Fig. 2). Garnets are enriched in Ti and $\mathrm{Zr}$ in samples derived from $>4 \mathrm{GPa}$, which corroborates the idea that metasomatism of this kind occurs within a restricted depth horizon (Yaxley et al. 2012), despite the apparent absence of a concomitant change in $f_{2}$. In contrast, Monk Hill samples show little deviation from normal patterns but are not HFSE enriched, and are thought to derive from too low pressures to have experienced the same style of metasomatism. $\mathrm{REE}_{\mathrm{N}}$ was parameterised following the method of O’Neill (2016) and a comparison with results from a global dataset will be presented.

\section{References}

Berry AJ, Yaxley GM, Woodland AB, Foran GJ (2010) A XANES calibration for determining the oxidation state of iron in mantle garnet. Chemical Geology 278:31-37

Boyd FR, Pearson DG, Hoal KO, Hoal BG, Nixon PH, Kingston MJ, Mertzman SA (2004) Garnet lherzolites from Louwrensia, Namibia: bulk composition and P/T relations. Lithos 77:573-592

Hanger BJ, Yaxley GM, Berry AJ, Kamenetsky VS (2015) Relationships between oxygen fugacity and metasomatism in the Kaapvaal subcratonic mantle, represented by garnet peridotite xenoliths in the Wesselton kimberlite, South Africa. Lithos 212-215:443-452

Mather KA, Pearson DG, McKenzie D, Kjarsgaard BA, Priestly K (2011) Constraints on the depth and thermal history of cratonic lithosphere from peridotite xenoliths, xenocrysts and seismology. Lithos 125:729-742

Miller WGR, Holland TJB, Gibson SA (2016) Garnet and spinel oxybarometers: new internally consistent multi-equilibria models with applications to the oxidation state of the lithospheric mantle. Journal of Petrology 57(6):1199-1222

Pearson DG, Irvine GJ, Ionov DA, Boyd FR, Dreibus GE (2004) Re-Os isotope systematics and platinum group element fractionation during mantle melt extraction: a study of massif and xenolith peridotite suits. Chemical Geology 208:29-59

O'Neill HSt.C (2016) The smoothness and shapes of chondrite-normalised rare earth element patterns in basalts. Journal of Petrology 57(8):1463-1508

Tappert R, Foden J, Muehlenbachs K, Wills K (2011) Garnet peridotite xenoliths and xenocrysts from the Monk Hill kimberlite, South Australia: Insights into the lithospheric mantle beneath the Adelaide Fold Belt. Journal of Petrology 52(10):1965-1986

Yaxley GM, Berry AJ, Kamenetsky VS, Woodland AB, Golovin AV (2012) An oxygen fugacity profile through the Siberian craton - Fe K-edge XANES determinations of $\mathrm{Fe}^{3+} / \sum \mathrm{Fe}$ in garnets from the Udachnaya East kimberlite. Lithos 140-141:142-151 